\title{
Hubungan antara jarak tempuh tes jalan 6 menit dan fraksi ejeksi pada pasien gagal jantung kronik terhadap kejadian kardiovaskular
}

\author{
${ }^{1}$ Agung D. Harikatang \\ ${ }^{2}$ Starry H. Rampengan \\ ${ }^{2}$ Edmond L. Jim \\ ${ }^{1}$ Kandidat Skripsi Fakultas Kedokteran Universitas Sam Ratulangi Manado \\ ${ }^{2}$ Bagian Kardiologi dan Kedokteran Vaskular Fakultas Kedokteran \\ Universitas Sam Ratulangi Manado \\ Email: agungh@hotmail.com
}

\begin{abstract}
Chronic heart failure (CHF) is a serious health problem with increasing incidence in developed and developing countries. CHF patients have decreased ejection fraction and distance in 6-minute walk test (6-MWT). It is a simple test that can be used in patients with CHF to assess the patient's functional capacity and prognosis in daily activities. This study aimed to determine the correlation between distance in 6 minutes walking test and ejection fraction in patients with CHF to cardiovascular events (re-hospitalization, stroke, cardiac death, and unstable angina). This was a prospective cohort study with an observational-analytical approach. Samples were 38 CHF patients obtained by using purposive sampling method Data were analyzed by using Chi-Square test. The results showed that of the total 31 CHF patients, there were 17 patients with $<300 \mathrm{~m}$ 6-MWT distance; $23.5 \%$ of them experienced cardiovascular events (re-hospitalization and unstable angina). Of the total CHF aptients, there were 14 respondents with 6 -MWT distance $>300 \mathrm{~m} ; 42.8 \%$ of them experienced cardiovascular events. The Chi-Square test showed that there was no significant correlation between the distance of 6-MWT and cardiovascular events $(\mathrm{p}=0.252)$. Of 7 patients with ejection fraction $<30 \%, 71.5 \%$ experienced cardiovascular events (re-hospitalization and unstable angina). However, of 24 samples with ejection fraction $>30-40 \%$, 20.8\% experienced cardiovascular events. The Chi-Square test showed that there was a significant correlation between ejection fraction and cardiovascular events $(\mathrm{p}=0,012)$. Conclusion: There was no significant correlation between distance in 6-minute walking test to cardiovascular events. Albeit, there was a significant correlation between ejection fraction and cardiovascular events.
\end{abstract}

Keywords: chronic heart failure, 6-minute walking test, ejection fraction

\begin{abstract}
Abstrak: Gagal jantung kronik (GJK) merupakan masalah kesehatan yang serius dengan angka kejadian yang terus meningkat. Pada GJK terdapat penurunan fraksi ejeksi dan gejala berupa sesak, kelelahan baik dalam keadaan istirahat maupun beraktivitas serta terjadi penurunan jarak tempuh tes jalan 6 menit. Tes jalan 6 menit merupakan uji yang sederhana dan murah yang digunakan pada penderita GJK untuk menilai kapasitas fungsional dan prognosis dalam beraktivitas. Penelitian ini bertujuan untuk mengetahui hubungan antara jarak tempuh tes jalan 6 menit dan fraksi ejeksi pada pasien GJK terhadap kejadian kardiovaskular (rehospitalisasi, stroke, kematian, dan unstable angina). Penelitian ini menggunakan studi kohort prospektif dengan pendekatan observasional-analitik. Sampel penelitian ini ialah pasien GJK yang diambil berdasarkan teknik purposive sampling dan dianalisis menggunakan uji Chi-Square. Hasil:
\end{abstract}


penelitian memperlihatkan dari total pasien GJK (n=31) didapatkan 17 sampel berjarak tempuh $<300$ m; 23,5\% di antaranya mengalami kejadian kardiovaskular (rehospitalisasi dan unstable angina). Responden dengan jarak tempuh $>300$ m berjumlah 14 orang; 42,8 \% mengalami kejadian kardiovaskular. Hasil uji Chi-Square menunjukkan tidak terdapat hubungan bermakna antara jarak tempuh tes jalan 6 menit dan kejadian kardiovaskular $(\mathrm{p}=0,252)$. Berdasarkan fraksi ejeksi, dari 7 pasien dengan fraksi ejeksi $<30 \%$ didapatkan $71,5 \%$ mengalami kejadian kardiovaskular (rehospitalisasi dan unstable angina) sedangkan dari 24 pasien dengan fraksi ejeksi $>30-40 \%$ didapatkan 20,8\% mengalami kejadian kardiovaskular. Hasil uji Chi-Square menunjukkan terdapat hubungan bermakna antara fraksi ejeksi dan kejadian kardiovaskular $(p=0,012)$. Simpulan: Tidak terdapat hubungan bermakna antara jarak tempuh tes jalan 6 menit dan kejadian kardiovaskular tetapi terdapat hubungan bermakna antara fraksi ejeksi dan kejadian kardiovaskular.

Kata kunci: Gagal jantung kronik, tes jalan 6 menit, fraksi ejeksi

Gagal jantung merupakan masalah kesehatan yang serius dengan angka kejadian yang terus meningkat baik di negara maju maupun negara berkembang. Gagal jantung didefinisikan sebagai suatu kondisi patologis, di mana jantung gagal memompa darah sesuai dengan kebutuhan jaringan untuk memenuhi kebutuhan metabolisme tubuh. ${ }^{1}$ Gagal jantung juga didefinisikan sebagai sindroma klinik yang memiliki gejala yang kompleks disertai keluhan-keluhan berupa sesak, kelelahan baik dalam keadaan istirahat maupun beraktivitas, disertai tanda-tanda retensi cairan seperti kongesti paru dan edema pergelangan kaki. ${ }^{2}$

Gagal jantung merupakan penyebab kematian serta disabilitas yang cukup besar. Walaupun perkembangan terapi saat ini yang semakin maju, angka mortalitas masih mencapai 20\% per tahun. Menurut American Heart Association 5,3 juta orang Amerika menderita gagal jantung kronik (GJK) dan 660.000 kasus baru terdiagnosis setiap tahun, dengan insiden 10 per 1000 orang. ${ }^{3}$ Menurut data Riskesdas 2013 jumlah penderita gagal jantung di Indonesia sekitar 229.696 orang dengan jumlah penderita terbanyak berada di Provinsi Jawa Timur yaitu sekitar 54.826 orang sedangkan Provinsi Maluku Utara dengan jumlah penderita terendah yaitu 144 orang. Provinsi Sulawesi Utara memiliki prevalensi penderita GJK dengan 2.378 orang dari total 240 juta penduduk di Indonesia. ${ }^{4,5}$

Pada penderita gagal jantung terdapat perubahan hemodinamik berupa penurunan curah jantung, volume sekuncup, dan fraksi ejeksi sehingga menyebabkan terjadinya gejala berupa sesak napas, kelelahan, dan intoleransi latihan fisik. Berkurangnya toleransi latihan merupakan faktor utama penurunan fungsi sosial, fisik, serta kualitas hidup dan meningkatkan kemungkinkan terjadinya kejadian kardiovaskular. ${ }^{6}$

Tes jalan 6 menit (6MWT, 6-minute walking test) merupakan uji yang bersifat sederhana, objektif, dan murah yang dapat dilakukan di klinik dengan manajemen waktu yang cepat dan efisien. Tes ini dapat digunakan untuk menilai kapasitas fungsional dan sangat berguna untuk menilai prognosis pasien dalam menjalani kehidupan sehari-hari. Menurut studi yang di lakukan oleh American Thoracic Society pada 117 laki-laki dan 173 wanita normal, kemampuan berjalan selama 6 menit adalah $580 \mathrm{~m}$ (pria) dan $500 \mathrm{~m}$ (wanita). Jarak ini bisa berubah berdasarkan faktor-faktor penentu seperti tinggi badan, berat badan, umur, dan adanya disabilitas pasien. $^{7,8}$

Menurut penelitian Carvalho et al. jarak tempuh tes jalan 6 menit adalah prediktor terhadap angka kematian dan rehospitalisasi pada pasien dengan gagal jantung. ${ }^{9}$ Hal ini didukung oleh hasil penelitian yang dilakukan Texas Heart Institute yang menyatakan resiko kematian ditemukan secara signifikan lebih tinggi pada pasien dengan jarak $\leq 300 \mathrm{~m}$ tes 
jalan 6 menit dan pasien dengan ejeksi fraksi ventrikel kiri (LVEF) $<30 \% .^{10}$

Penelitian ini bertujuan untuk mengetahui apakah terdapat hubungan antara jarak tempuh tes jalan 6 menit (6 MWT) dan fraksi ejeksi pada pasien GJK terhadap kejadian kardiovaskular.

\section{METODE PENELITIAN}

Penelitian ini merupakan studi kohort prospektif dengan menggunakan metode analitik observasional untuk mengetahui hubungan antara jarak tempuh tes jalan 6 menit dan fraksi ejeksi pada pasien gagal jantung kronik periode Oktober-Desember 2015 terhadap kejadian kardiovaskular.

Populasi penelitian ialah pasien GJK yang berobat di Poliklinik Jantung RSUP Prof. Dr. R. D. Kandou Manado. Sampel penelitian ialah pasien GJK yang diambil dengan menggunakan teknik consecutive sampling, yaitu pasien yang menderita gagal jantung >6 bulan dengan etiologi infark miokard akut (IMA), penyakit jantung koroner (PJK) dan atau penyakit jantung hipertensi (PJH), memiliki fraksi ejeksi $\leq 40 \%$ dan bersedia mengikuti penelitian dengan menandatangani informed consent.

Jenis data yang digunakan ialah data primer. Pengumpulan data dilakukan dengan melakukan tes jalan 6 menit (6MWT). Fraksi Ejeksi responden diukur menggunakan parameter ekokardiografi. Pengolahan dan analisis data menggunakan program komputer SPSS versi 20. Jenis analisis data yang digunakan yaitu analisis deskriptif untuk melihat distribusi responden dan analisis uji tabulasi silang untuk melihat hubungan antara jarak tempuh 6MWT dan fraksi ejeksi terhadap kejadian kardiovaskular. Data disajikan dalam bentuk tabel distribusi frekuensi dan tabel uji tabulasi silang jarak tempuh dan fraksi ejeksi terhadap kejadian kardiovaskular.

\section{HASIL PENELITIAN}

Didapatkan total 46 pasien CHF selama periode Oktober-Desember 2015, tetapi hanya 35 responden yang memenuhi kriteria inklusi dengan jumlah 31 responden yang berhasil menyelesaikan 6MWT dan dipantau selama 2 bulan.

Berdasarkan Tabel 1 tentang karakteristik responden didapatkan 24 responden laki-laki $(77,4 \%)$ dan 7 responden perempuan $(22,5 \%)$, dimana dari total 10 responden yang mengalami kejadian kardiovaskular 90\% diantaranya berjenis kelamin laki-laki dan perempuan hanya $10 \%$. Dari total 21 responden yang tidak mengalami kejadian kardiovaskular didapatkan 71,4\% diantaranya laki-laki dan 28,6\% perempuan. Hasil uji statistik didapatkan $p=0,284$ yang menunjukkan tidak terdapat hubungan bermakna antara jenis kelamin responden dengan kejadian kardiovaskular.

Rerata usia responden penelitian ialah $60,5 \pm 7,40$ tahun. Kelompok usia terbanyak ialah kelompok 60-70 tahun dimana dari total 10 responden mengalami kejadian kardiovaskular terdapat $50 \%$ responden dari kelompok usia ini, sedangkan yang terendah pada kelompok usia 40-49 tahun sebesar 10\%. Hasil uji tabulasi silang $p=0,288$ menunjukkan tidak terdapat hubungan bermakna antara usia pasien GJK dengan kejadian kardiovaskular.

Berdasarkan penyebab penyakit terdahulu didapatkan 16 responden (51,6\%) dengan PJK, 13 responden (41,9\%) PJK dan PJH, dan 2 responden (6,5\%) dengan PJH. Dari total 10 responden berkejadian kardiovaskular didapatkan 5 responden (50\%) dengan penyakit terdahulu PJK dan 5 responden (50\%) dengan penyakit terdahulu PJK dan PJH. Dari total 21 responden yang tidak mengalami kejadian kardiovaskular, responden dengan penyakit terdahulu PJK yang terbanyak dengan 11 responden (52,4\%). Hasil uji statistik $p=0,552$ menunjukkan tidak terdapat hubungan bermakna antara penyebab penyakit terdahulu responden dengan kejadian kardiovaskular.

Berdasarkan hasil penelitian, rerata nilai 
fraksi ejeksi responden 32,82 \pm 7,30\% dengan pasien yang memiliki fraksi ejeksi $<30 \%$ sebanyak 7 responden dan responden dengan fraksi ejeksi $>30-40 \%$ sebanyak 24 responden. Didapatkan 50\% respoden yang mengalami kejadian kardiovaskular yaitu responden dengan fraksi ejeksi $<30 \%$ dan $50 \%$ lainnya ialah responden dengan fraksi ejeksi $>30-40 \%$. Hasil statistik uji tabulasi silang menghasilkan $p=0,012$ yang menunjukkan terdapat hubungan bermakna antara fraksi ejeksi dengan kejadian kardiovaskular.

Dari riwayat obat-obatan yang dikonsumsi responden didapatkan sebagian besar (87\%) responden menggunakan beta blocker diikuti 74,1\% responden mengonsum- si ACE inhibitor dan 48,5\% responden menggunakan nitrat maupun $38,7 \%$ responden memakai diuretik, sedangkan 25,8\% responden mengonsumsi angiotensin receptor blocker (ARB). Didapatkan angka kejadian kardiovaskular tertinggi pada responden yang menggunakan beta blocker yakni 90\% dari total 10 responden yang mengalami kejadian kardiovaskular dan angka kejadian kardiovaskular terendah pada responden yang menggunakan ARB yaitu 20\% dari total 10 responden dengan kejadian kardiovaskular.

Hasil uji tabulasi silang $p=0,394$ menunjukkan tidak terdapat hubungan yang bermakna antara riwayat konsumsi obat responden dengan kejadian kardiovaskular.

Tabel 1. Data Karakteristik Pasien Gagal Jantung Kronik berdasarkan Kejadian Kardiovaskular

\begin{tabular}{|c|c|c|c|c|}
\hline \multirow[t]{2}{*}{ Karakteristik } & \multicolumn{4}{|c|}{ Kejadian Kardiovaskular } \\
\hline & $\begin{array}{l}\text { Rata-rata } \pm \text { SB } \\
\quad(n=31)\end{array}$ & $\begin{array}{c}\text { Tidak Ada } \\
(n=21)\end{array}$ & $\begin{array}{c}\text { Ada } \\
(n=10)\end{array}$ & Nilai $p$ \\
\hline \multicolumn{5}{|l|}{ Jenis Kelamin } \\
\hline Laki-Laki & $24(77,4 \%)$ & 15 (71,4\%) & $9(90 \%)$ & \multirow{2}{*}{0,248} \\
\hline Perempuan & $7(22,6 \%)$ & $6(28,6 \%)$ & $1(10 \%)$ & \\
\hline \multicolumn{5}{|l|}{ Usia (Tahun) } \\
\hline $40-49$ & & - & $1(10 \%)$ & \multirow{3}{*}{0,288} \\
\hline $50-59$ & $60,51 \pm 7,40$ & $7(33,3 \%)$ & $4(40 \%)$ & \\
\hline $60-70$ & & $14(66,7 \%)$ & $5(50 \%)$ & \\
\hline \multicolumn{5}{|l|}{ Penyakit Terdahulu } \\
\hline PJK & $16(51,6 \%)$ & $11(52,4 \%)$ & $5(50 \%)$ & \multirow{3}{*}{0,552} \\
\hline PJH & $2(6,5 \%)$ & $2(9,5 \%)$ & - & \\
\hline PJK \& PJH & $13(41,9 \%)$ & $8(38,1 \%)$ & $5(50 \%)$ & \\
\hline \multicolumn{5}{|l|}{ Fraksi Ejeksi (\%) } \\
\hline$<30$ & $3283+730$ & $2(9,5 \%)$ & $5(50 \%)$ & \multirow{2}{*}{$0,012 *$} \\
\hline$>30-40$ & $32,83 \pm 1,30$ & $19(90,5 \%)$ & $5(50 \%)$ & \\
\hline \multicolumn{5}{|l|}{ Obat-obatan } \\
\hline ACE Inhibitor & $23(74,1 \%)$ & $15(71,4 \%)$ & $8(80 \%)$ & \multirow{6}{*}{0,394} \\
\hline Beta Blocker & 27 (87\%) & $18(85,7 \%)$ & $9(90 \%)$ & \\
\hline Nitrat & $15(48,3 \%)$ & $8(38,1 \%)$ & $7(70 \%)$ & \\
\hline Diuretik & $12(38,7 \%)$ & $7(33,3 \%)$ & $5(50 \%)$ & \\
\hline Angiotensin Receptor & $8(25,8 \%)$ & $6(28,6 \%)$ & $2(20 \%)$ & \\
\hline \multirow{2}{*}{\multicolumn{5}{|c|}{$\begin{array}{l}\text { Blocker } \\
\text { Jarak Tempuh 6MWT (m) }\end{array}$}} \\
\hline & & & & \\
\hline$<300$ & \multirow{2}{*}{$301,09 \pm 80,18$} & $13(61,9 \%)$ & $4(40 \%)$ & \multirow[t]{2}{*}{0,252} \\
\hline$>300$ & & $8(38,1 \%)$ & $6(60 \%)$ & \\
\hline
\end{tabular}

Berdasarkan data hasil penelitian ini, rerata jarak tempuh responden adalah 301,90 $\pm 80,18 \mathrm{~m}$. Dari total 10 responden yang mengalami kejadian kardiovaskular didapatkan $40 \%$ responden berjarak tempuh $<300 \mathrm{~m}$ dan $60 \%$ responden berjarak tempuh $>300 \mathrm{~m}$, 
sedangkan dari total 21 responden yang tidak mengalami kejadian kardio-vaskular, 61,9\% berjarak tempuh <300 m dan 38,1\% berjarak tempuh $>300 \mathrm{~m}$. Hasil uji tabulasi silang dengan nilai $p=0,252$ maka disimpulkan tidak terdapat hubungan yang bermakna antara jarak tempuh tes jalan 6 menit dengan kejadian kardiovaskular.

Tabel 2. Distribusi Sampel Berdasarkan Jenis Kelamin

\begin{tabular}{ccc}
\hline Jenis Kelamin & $\mathrm{n}$ & $\%$ \\
\hline Laki-Laki & 24 & 77,4 \\
Perempuan & 7 & 22,6 \\
Total & 31 & 100,0 \\
\hline
\end{tabular}

Dari hasil penelitian menunjukan bahwa jumlah responden laki-laki adalah sebanyak 24 orang $(77,4 \%)$ dan 7 responden perempuan $(22,6 \%)$.

Tabel 3. Distribusi Sampel Berdasarkan Usia

\begin{tabular}{ccc}
\hline Usia (Tahun) & $\mathrm{n}$ & $\%$ \\
\hline $40-49$ & 1 & 3,2 \\
$50-59$ & 11 & 35,5 \\
$60-70$ & 19 & 61,3 \\
Total & 31 & 100,0 \\
\hline
\end{tabular}

Dari hasil penelitian menunjukkan bahwa jumlah responden kelompok usia 40-49 tahun adalah 1 orang (3,2\%), kelompok usia 50-59 tahun sebanyak 11 orang (35,5\%) dan responden terbanyak berada pada kelompok usia 60-70 tahun yakni sebanyak 19 orang (61,3\%).

Tabel 4. Distribusi Sampel Berdasarkan Penyakit Terdahulu

\begin{tabular}{lcc}
\hline $\begin{array}{l}\text { Penyakit } \\
\text { Terdahulu }\end{array}$ & $\mathrm{n}$ & $\%$ \\
\hline PJK & 16 & 51,6 \\
PJH & 2 & 6,5 \\
PJK \& PJH & 13 & 41,9 \\
Total & 31 & 100,0 \\
\hline
\end{tabular}

Dari hasil penelitian menunjukan bahwa jumlah responden terbanyak adalah dengan penyakit terdahulu PJK yakni sebanyak 16 orang (51,6\%), kemudian penyakit terdahulu PJK \& PJH 13 orang (41,9\%) dan penyakit terdahulu PJH sebanyak 2 orang (6,5\%).

Tabel 5. Distribusi sampel berdasarkan jarak tempuh tes jalan 6 menit

\begin{tabular}{lcc}
\hline $\begin{array}{l}\text { Jarak tempuh } \\
6 \text { MWT }\end{array}$ & $\mathrm{n}$ & $\%$ \\
\hline$<300 \mathrm{~m}$ & 17 & 54,8 \\
$>300 \mathrm{~m}$ & 14 & 45,2 \\
Total & 31 & 100,0 \\
\hline
\end{tabular}

Dari hasil penelitian didapatkan responden yang berjalan $<300 \mathrm{~m}$ yakni sebanyak 17 orang (54.8\%) dan $>300 \mathrm{~m}$ sebanyak 14 orang (45.2\%).

Tabel 6. Distribusi sampel berdasarkan nilai fraksi ejeksi

\begin{tabular}{lcc}
\hline Fraksi Ejeksi & $\mathrm{n}$ & $\%$ \\
\hline$<30 \%$ & 7 & 22,6 \\
$>30-40 \%$ & 24 & 77,4 \\
Total & 31 & 100,0 \\
\hline
\end{tabular}

Dari hasil penelitian didapatkan responden dengan Fraksi ejeksi $<30 \%$ adalah sebanyak 7 responden (22,6\%) dan $>30-40 \%$ adalah sebanyak 24 responden $(77,4 \%)$.

Tabel 7. Distribusi sampel berdasarkan kejadian kardiovaskular

\begin{tabular}{lcc}
\hline $\begin{array}{l}\text { Kejadian } \\
\text { Kardiovaskular }\end{array}$ & $\mathrm{N}$ & $\%$ \\
\hline Rehospitalisasi & 6 & 19,4 \\
Stroke & - & - \\
Kematian & - & - \\
Unstable Angina & 4 & 12,9 \\
Tidak ada & 21 & 67,7 \\
Total & 31 & 100,0 \\
\hline
\end{tabular}

Dari hasil penelitian terhadap 31 responden, didapatkan responden dengan 
kejadian kardiovaskular terbanyak yakni rehospitalisasi 6 orang (19,4\%), Stroke dan kematian tidak ada, unstable angina 4 orang (12,9\%), sedangkan yang tidak mengalami Kejadian kardiovaskular sebanyak 21 orang $(67,7 \%)$.

Hasil penelitian menunjukkan bahwa terdapat 3 orang responden dengan jarak tempuh $<300 \mathrm{~m}$ mengalami rehospitali-sasi (17,6\%), 1 orang mengalami unstable angina (5,9\%), dan 13 responden (76,5\%) tidak ada kejadian kardiovaskular. Responden dengan jarak tempuh $>300 \mathrm{~m}$, didapatkan 3 respoden mengalami rehospi-talisasi (21,4\%), 3 responden lainya mengalami unstable angina (21,4\%), dan yang tidak mengalami kejadian kardiovaskular sebanyak 8 responden (57,1\%). Dari total 31 responden penelitian, didapatkan 10 responden (32,3\%) mengalami kejadian kardiovaskular sedang-kan 21 responden $(67,7 \%)$ tidak mengalami kejadian kardiovaskular. Nilai $p=0,252$ menunjukkan tidak terdapat hubungan bermakna antara jarak tempuh tes jalan 6 menit dengan kejadian kardiovaskular.

Tabel 8. Hubungan antara jarak tempuh tes jalan 6 menit dengan kejadian kardiovaskular

\begin{tabular}{|c|c|c|c|c|c|c|c|c|}
\hline & & \multicolumn{5}{|c|}{ Kejadian Kardiovaskular } & \multirow[b]{2}{*}{ Total } & \multirow[b]{2}{*}{ Nilai $p$} \\
\hline & & Rehospitalisasi & Stroke & Kematian & $\begin{array}{c}\text { Unstable } \\
\text { Angina }\end{array}$ & $\begin{array}{c}\text { Tidak } \\
\text { ada }\end{array}$ & & \\
\hline \multirow{4}{*}{$\begin{array}{c}\text { Jarak } \\
\text { tempuh } \\
6 \mathrm{MWT}\end{array}$} & \multirow{2}{*}{$<300 \mathrm{~m}$} & 3 & - & - & 1 & 13 & 17 & \multirow{4}{*}{0,252} \\
\hline & & $17,6 \%$ & - & - & $5,9 \%$ & $76,5 \%$ & $100 \%$ & \\
\hline & \multirow{2}{*}{$>300 \mathrm{~m}$} & 3 & - & - & 3 & 8 & 14 & \\
\hline & & $21,4 \%$ & - & - & $21,4 \%$ & $57,1 \%$ & $100 \%$ & \\
\hline \multirow{2}{*}{\multicolumn{2}{|c|}{ Total }} & 6 & - & - & 4 & 21 & 31 & \\
\hline & & $19,4 \%$ & - & - & $12,9 \%$ & $67,7 \%$ & $100 \%$ & \\
\hline
\end{tabular}

Dianalisis menggunakan uji tabulasi silang $\left(X^{2}\right)$

Tabel 9. Hubungan Fraksi Ejeksi dengan Kejadian Kardiovaskular

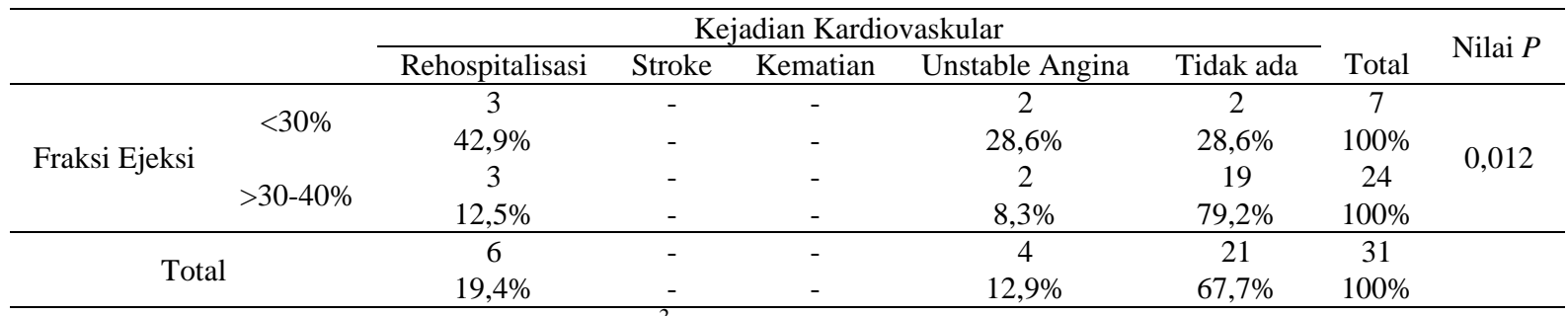

Dianalisis menggunakan uji tabulasi silang $\left(X^{2}\right)$

Dari hasil penelitian menunjukan bahwa terdapat 3 responden dengan Fraksi Ejeksi $<30 \%$ mengalami reshospitalisasi (42,9\%), 2 responden mengalami unstable angina (28,6\%) dan 2 responden (28,6\%) lainnya didapatkan tidak ada kejadian kardiovaskular. Pada responden dengan Fraksi Ejeksi >30$40 \%$ didapatkan 3 responden mengalami rehospitalisasi (12,5\%), 2 responden unstable angina (8,3\%), dan 19 responden (79,2\%) tidak ada kejadian kardiovaskular. Dari 31 responden penelitian, didapatkan 5 dari total 7 responden dengan fraksi ejeksi $<30 \%$ mengalami kejadian kardiovaskular dan 5 dari total 24 responden dengan fraksi ejeksi $>30$ $40 \%$ yang mengalami kejadian kardiovaskular. Nilai $p=0,012$ menunjukkan bahwa terdapat hubungan yang bermakna antara 
fraksi ejeksi dengan kejadian kardiovaskular.

\section{BAHASAN}

Hasil analisis statistik menunjukkan tidak terdapat hubungan signifikan antara jarak tempuh tes jalan 6 menit dengan kejadian kardiovaskular pada pasien GJK di RSUP. Prof. R. D. Kandou Manado $(p=0,252)$. Hasil ini tidak sesuai dengan penelitian yang dilakukan Wegrznowska et al. yang menyatakan bahwa terdapat hubungan yang signifikan antara jarak tempuh tes jalan 6 menit dengan kejadian kardiovaskular (kematian dan rehospitalisasi) pada pasien GJK. ${ }^{11}$ Hasil ini juga bertolak belakang dengan penelitian Aladeb et al. yang menyatakan jarak tempuh tes jalan 6 menit adalah prediktor kuat terhadap angka rehospitalisasi jangka panjang pada penderita gagal jantung. ${ }^{12}$ Tidak adanya hubungan bermakna dalam penelitian ini kemungkinan di karenakan jumlah sampel yang sedikit, kurun waktu follow up yang singkat, dan rentang waktu periode penelitian yang singkat dibandingkan penelitian lain.

Hasil analisis statistik menunjukan terdapat hubungan yang bermakna antara fraksi ejeksi dengan kejadian kardiovaskular pada pasien Gagal Jantung Kronik di RSUP. Prof. R. D. Kandou Manado $(p=0,012)$. Hal ini didukung oleh penelitian Cardiology Department Ataturk Turkey yang menyatakan bahwa terdapat hubungan yang bermakna antara ejeksi fraksi dan kejadian kardiovaskular (rehospitalisasi dan kematian). ${ }^{13}$ Terdapatnya hubungan antara fraksi ejeksi dengan kejadian kardiovaskular dapat terjadi karena keseluruhan responden penelitian memiliki fraksi ejeksi $<40 \%$ yang berarti kemampuan pompa jantung sudah menurun dari nilai normal 65\%, dan darah kaya oksigen yang dipompa jantung ke seluruh organ tubuh sudah tidak dalam jumlah yang maksimal. Ini menyebabkan jantung melakukan mekanisme homeostasis dengan mengaktifkan sistem saraf simpatis dan Renin angiotensin aldosterone (RAA). Mekanisme ini dapat mengakibatkan peningkatan volume preload, afterload, sehingga pada akhirnya dapat menurunkan kontraktilitas dan curah jantung. Hal ini meningkatkan resiko terjadinya kejadian kardiovaskular pada pasien GJK seperti sudden cardiac death. ${ }^{14,15}$

\section{Limitasi penelitian}

Dalam penelitian ini jumlah sampel yang digunakan kecil, rentang waktu follow up singkat, serta periode penelitian yang pendek sehingga tidak didapatkan hasil penelitian yang optimal.

\section{SIMPULAN}

Dari hasil penelitian yang dilakukan di Poliklinik Jantung RSUP Prof. Dr. R. D. Kandou Manado dapat disimpulkan bahwa tidak terdapat hubungan bermakna antara jarak tempuh tes jalan 6 menit dengan kejadian kardiovaskular. Terdapat hubungan bermakna antara fraksi ejeksi dengan kejadian kardiovaskular yaitu semakin rendah fraksi ejeksi maka semakin tinggi kemungkinan mengalami kejadian kardiovaskular.

\section{DAFTAR PUSTAKA}

1. Squire I. Aetiology and epidemiology of chronic heart failure. In: Kearney $\mathrm{M}$, editor. Chronic heart failure (1st ed). Leeds: Oxford Cardiology Library, 2008; p. 1-9.

2. Bambang BS, Nani H, Erwinanto, Rossana B, Rarsari SP, Siti EN, et al. Pedoman tatalaksana gagal jantung. Jakarta: Perhimpunan Dokter Spesialis Kardiovaskular Indonesia, 2015;p. 1-35.

3. Nasif M. Epidemiology. In: Alahmad A, editor. Congestive Heart Failure and Public Health, 2006; p. 1-2.

4. Yasmin T, Ismoyo S, Basuni R. Disfungsi autonom pada pasien penyakit jantung hipertensi asimptomatik. J Kardiol Indones. 2008;29:97-104.

5. Berisha V, Bajraktari G, Dobra D, Haliti E, Bajrami R, Elezi S. Echocardiography and 6-minute walk test in left ventricular systolic dysfunction. Arq Bras Cardiol 


\section{J. 2009;92(2).}

6. Kementerian Kesehatan RI. Badan Litbangkes Kementerian Kesehatan RI dan Data Penduduk Sasaran. Data Riset Kesehatan Dasar 2013; p. 2-4.

7. Kervio G, Ville NS, Leclercq C, Daubert JC, Carré F. Examination of the six minute walk test to determine functional capacity in people with chronic heart failure. Cardiopulm Phys Ther J. 2010; 21(1):1321.

8. American Thoracic Society. Background and Interpreting Single Measurements of Functional Status. Guidelines for the SixMinute Walk Test. Am J Respir Crit Care Med. 2002;166:111-7.

9. Eduardo EC, Daniela CC, Júlio CC, Giovani LDS, Valéria P, Fabiana M, et al. Heart failure: comparison between six-minute walk test and cardiopulmonary test. Departamento de clínica médica med J. 2011;4:5.

10. Sakir A, Mustafa KE, Fuat G, Serdar S, Enbiya A, Huseyin S, et al. Prognostic Value of 6-Minute Walk Test in Stable Outpatients with Heart Failure. Tex Heart Inst J. 2007;34(2):166-9.
11. Kinga WT, Eliza R, Malgorzata $\mathbf{L}$, Katarzyna N, Waldermar B, Piotr P, et al. Distance covered during a six-minute walk test predicts long-term cardiovascular mortality and hospitalization rates in man with systolic heart failure. $\mathrm{J}$ of Physiotherapy. 2013;177-86.

12. Tarek A, John S, Ibrahim M, Sirikam N, et al. Six minute walk test predicts Longterm all-cause mortality and hf rehospitalization in African American Heart Failure patients. American Heart Association J. 2008;118;11.

13. Sakir A, Mustafa KE, Fuat G, Serdar S, Enbiyi A, Huseyin S, et al. Prognostic value of 6-minute walk test in stable outpatients with heart failure. Tex Heart Inst J. 2007;43(2):166-9.

14. Brasher VL. Aplikasi klinis patofisiologi: pemeriksaan dan manajemen (2nd ed). Jakarta: Buku kedokteran EGC, 2008; p. 53-4.

15. Aoronson PI, Ward JP. At a glance sistem kardiovaskular (3rd ed). Jakarta: Penerbit Erlangga; 2008. 